\title{
Heterogeneity of terrestrial bromeliad colonies and regeneration of Acacia praecox (Fabaceae) in a humid-subtropical-Chaco forest, Argentina
}

\author{
Ignacio M. Barberis \& Juan Pablo Lewis \\ Facultad de Ciencias Agrarias, Universidad Nacional de Rosario. Casilla de correo 14, S2125ZAA, Zavalla, Argentina. FAX \\ 54-341-4970080. Consejo Nacional de Investigaciones Científicas y Técnicas (CONICET). ibarberi@fcagr.unr.edu.ar \\ Received 12-VII-200. C Corrected 22-IV-2005. Accepted 22-IV-2005.
}

\begin{abstract}
In several tropical and subtropical forests, plants of the understorey act as an ecological filter that differentially affects woody species regeneration. In convex sectors of the Schinopsis balansae (Anacardiaceae) forests of the Southeastern Chaco there are dense colonies of terrestrial bromeliads. These may influence forest regeneration by intercepting rain water and propagules in their tanks. Within colonies, the spatial distribution of bromeliads is clumped because their clonal growth leaves numerous internal gaps. In this study we describe the internal heterogeneity of three bromeliad colonies (plots) and analyze how this heterogeneity affects Acacia praecox regeneration (i.e. seedling recruitment and survival). In January 1996, we randomly placed three transects with 150 contiguous quadrats of $100 \mathrm{~cm}^{2}$ in each plot. For each quadrat we recorded the type of floor cover (i.e. bromeliads, herbs, litter, or bare soil) and the presence of A. praecox seeds or seedlings. In July 1996 we relocated the transects and recorded seedling survival. Bromeliad colonies showed a high internal heterogeneity. Almost half of the 450 quadrats were covered by two terrestrial bromeliads. Aechmea distichantha was recorded in $81 \%$ of all quadrats with bromeliads, and Bromelia serra in the others. All quadrats with bromeliads were covered by litter. Half of them were occupied by the bases of bromeliads and the others were covered by their leaves. In contrast, where bromeliads were not present, soil surface was covered by litter in $83 \%$ and by herbaceous vegetation in $11 \%$ of the quadrats; very few quadrats were covered by bare soil. In January 1996, we recorded 127 seeds and 176 seedlings of A. praecox. Seed and seedling densities of A. praecox were similar in quadrats with and without bromeliads, but variability in seedling density of A. praecox was higher within than among plots. Seed density was higher in quadrats covered by bromeliad leaves than inside the tanks. Seedling survival of A. praecox was slightly higher in quadrats with bromeliads in only one of the three plots. No seedling survived inside the bromeliad tanks. Apparently, bromeliad colonies have no effect on seedling regeneration of A. praecox. Rev. Biol. Trop. 53(3-4): 377-385. Epub 2005 Oct 3.
\end{abstract}

Key words: Bromeliads, Chaco, heterogeneity, regeneration, Schinopsis balansae, understorey.

Spatial patterns of woody species regeneration are often associated with environmental heterogeneity (Streng et al. 1989, Svenning 1999, 2001). The environmental factors responsible for these spatial patterns varied according to the analyzed scale (Kolasa and Pickett 1991). At a broad scale, topography and soil heterogeneity often determine spatial patterns of woody species regeneration. At a finer scale, the effects of these factors may be affected by disturbances related to animal activity and treefalls (Orians 1982, Beatty and Stone 1986, Nakashizuka 1989, Pire et al. 1991, Hansell 1993, Itoh 1995). In addition, understorey plants with clonal growth or limited dispersion such as ferns, bamboos, palms, bromeliads, etc. may reinforce or change these regeneration patterns (Bordón 1978, Martínez Crovetto 1980, Brokaw 1983, Taylor and Qin 1988, Denslow et al. 1991, Wada 1993, Takahashi 1997, George and Bazzaz 1999a, b, Marod et al. 1999, Takahashi and Kohyama 1999, Tabarelli and Mantovani 2000, Abe et al. 2001, Sugita and Tani 2001). 
In several forests, dense plant colonies in the understorey affect woody species regeneration through competition for light, water, and soil nutrients, reduction of the physical space where to establish, as well as providing shelter for seed and seedling predators (Denslow et al. 1991, Wada 1993, George and Bazzaz 1999a, b, Abe et al. 2001). In some tropical and subtropical forests, colonies of terrestrial bromeliads may intercept rainwater and propagules in their tanks (Bordón 1978, Martínez Crovetto 1980, Brokaw 1983). Within colonies, the spatial distribution of bromeliads is clumped due to their clonal growth leaving numerous internal gaps. This finer heterogeneity may also affect forest regeneration by allowing woody seedling establishment in these empty microsites between bromeliads. Moreover, dense colonies of spiny species (e.g. terrestrial bromeliads with armed leaves) may increase seedling survival by reducing the access of large mammals into the interior of the colonies (Bordón 1978, Martínez Crovetto 1980, Pire and Prado 2001). Therefore, in forests with a dense understorey it is necessary to characterize the relationship between the heterogeneity of the understorey and forest regeneration.

In the southern portion of the Eastern Chaco, the 'quebrachales' of Schinopsis balansae Engl. (Anacardiaceae) are open forests with a high internal heterogeneity (Lewis and Pire 1981, Lewis 1991, Lewis et al. 1997, Barberis et al. 1998). In this type of forest, differences in topography and soil moisture determine habitats with different floristic and structural characteristics (Lewis et al. 1997, Barberis et al. 1998, Barberis et al. 2002). Convex sectors have a high density of woody individuals, and their dominant species are trees and shrubs (Barberis et al. 2002), whereas plain sectors and depressions are covered by herbaceous vegetation, and very few individuals which are mainly trees. In many convex sectors there are dense colonies of terrestrial bromeliads locally known as 'cardales' or 'caraguatales', frequently dominated by Aechmea distichantha Lemaire and Bromelia serra Gris. (Lewis and Pire 1981, Pire and Prado 2001). Often, these colonies constitute the matrix of the forest understorey, whereas the other woody and herbaceous species establish in the spaces left among the bromeliads.

In a regeneration study of a 'quebrachal' of the Southern Chaco there were no significant differences in woody seedling density between sectors with and without bromeliads (Barberis 1998). However, that study did not analyze whether the internal heterogeneity of the bromeliad colonies affected in different ways particular regeneration processes (e.g. seedling recruitment or survival). Contrasting responses to some factors have been observed among different regeneration processes in several temperate and tropical forests (Schupp 1995). Thus, the objects of this paper are (1) to describe the internal heterogeneity of the bromeliad colonies of the 'quebrachal', and (2) to analyze how this heterogeneity may affect woody species regeneration (i.e. seedling recruitment and survival).

\section{MATERIAL AND METHODS}

Study area: The Gran Chaco is the second largest phytogeographic unit of the Neotropics and spreads over N Argentina, W Paraguay, E Bolivia, and a small portion of SW Brazil (Prado 1993). It encompasses a mosaic of dry forests, savannas, grasslands, and wetlands (Morello and Adámoli 1974, Prado 1993). In the southern portion of the Eastern Chaco (i.e. Cuña Boscosa Santafesina), communities are arranged along environmental gradients related to topographic elevation (Lewis and Pire 1981). At the top of the gradient are the mixed dense forests, then the $S$. balansae forests (quebrachales), which are the most widespread and characteristic type of forest of the area, and at the bottom, close to wetlands, are the Prosopis nigra (Gris.) Hier. var. ragonesei Burk. forests (algarrobales) or palm groves of Copernicia alba Morong. (Lewis and Pire 1981, Lewis 1991, Lewis et al. 1994). 
Study site: The study was carried out in Centro Operativo Tito Livio Coppa, located in Las Gamas, close to Vera, Santa Fe, Argentina $\left(29^{\circ} 28^{\prime} \mathrm{S}, 60^{\circ} 28^{\prime} \mathrm{W}, 58 \mathrm{~m}\right.$ above sea level). This site is characterized by an almost nil relief and a mosaic of halo-hydromorphic soils (Espino et al. 1983). Climate is temperate warm, with a mean annual temperature about $20^{\circ} \mathrm{C}$ and absolute maximum and minimum of $42.8^{\circ} \mathrm{C}$ and $-5.6^{\circ} \mathrm{C}$ respectively. The mean annual rainfall is $1090 \mathrm{~mm}$, and there is a large variability among total annual records, ranging from $1400 \mathrm{~mm}$ to $700 \mathrm{~mm}$ (Espino et al. 1983). This stand of the 'quebrachal', like most other forests of the Cuña Boscosa Santafesina, has been lumbered for tannin extraction (Bitlloch and Sormani 1997). Nowadays, cattle grazing and sporadic fires are the main disturbances.

Sampling and data analysis: In January 1996 we characterized the soil cover of three bromeliad colonies (plots) from a stand of S. balansae forest. In each plot we randomly placed three transects with 50 contiguous quadrats each. In each quadrat $\left(100 \mathrm{~cm}^{2}\right)$ we recorded the presence of terrestrial bromeliads A. distichantha or B. serra. In sites without bromeliads we distinguished whether the quadrat was covered with litter, herbs, or others (i.e. stems, dungs, ant-nests, or bare soil), whereas in sites with bromeliads (i.e. A. distichantha and B. serra) we distinguished whether the quadrat was beneath bromeliad leaves or occupied by the base of the plant. Similarly, in each quadrat we recorded the number of seeds and seedlings of woody species. As all newly emerged seedlings were Acacia praecox Gris. and the number of old seedlings (i.e. individuals $<30 \mathrm{~cm}$ in height) was very low (i.e. 17 individuals belonging to 6 species), we only considered A. praecox for the analysis.

To evaluate the internal heterogeneity of bromeliad colonies we estimated the coefficient of variation $(\mathrm{CV}=100 \mathrm{~s} / \mathrm{x})$ for the number of quadrats with and without bromeliad cover in each plot (i.e. three transects with 50 quadrats each) and for all plots together (i.e. three plots with 150 quadrats each).
To estimate whether there were differences in seed and seedling density of A. praecox between quadrats with and without bromeliads we used the Wilcoxon non-parametric tests for paired data (Zar 1999). We used the same tests to evaluate differences in seed and seedling density between quadrats covered by bromeliad leaves or bases. We also estimated the $\mathrm{CV}$ to evaluate variations in seed and seedling density of A. praecox within and between plots.

In July 1996 we recorded whether seedlings of A. praecox recruited in January were still alive or dead. For each plot we estimated seedling survival using the following equation: $\mathrm{S}=100 \mathrm{~N}_{\text {Final }} / \mathrm{N}_{\text {Initial }}$, where $\mathrm{S}$ was the percentage of surviving seedlings, $\mathrm{N}_{\text {Final }}$ and $\mathrm{N}_{\text {Initial }}$ were the number of surviving seedlings in July and January 1996 respectively. For each plot and for the set of plots, we made confidence intervals based on the binomial distribution of the surviving seedlings in quadrats with or without bromeliads. We used the chi-square test to evaluate whether there was association between bromeliad presence and seedling survival (Zar 1999).

In all these analyses we did not distinguished whether the bromeliad was A. distichantha or B. serra.

\section{RESULTS}

Almost half of the 450 quadrats were covered by bromeliads (45\%). A. distichantha was recorded in $81 \%$ of all quadrats with bromeliads, and B. serra in the others. In all quadrats with bromeliads, soil surface was covered by litter. About half of them were covered with bromeliad leaves (54\%) and the remainders were occupied by their bases (46\%; Fig. 1a). In contrast, where there were no bromeliads, soil surface was covered by litter in $83 \%$ of the quadrats, by herbaceous vegetation in $11 \%$, and very few quadrats with ant-nests, cattle-dung, or bare ground (Fig. 1b).

A high variation among transects was observed in all plots. The number of quadrats with and without bromeliads was more variable 


\section{a) With bromeliads}

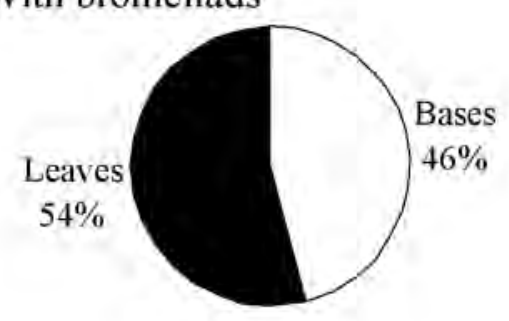

b) Without bromeliads

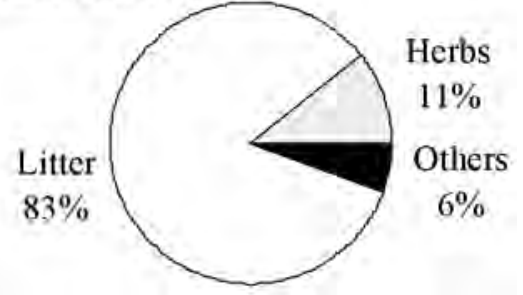

Fig. 1. a) Percentage of quadrats covered by bromeliad leaves or ocuppied by their bases, and b) Percentage of quadrats without bromeliads that are covered by litter, herbs, and others (ant-nests, cattle-dung, or bare ground).

within each plot than for the whole set of plots (Table 1). There were also marked differences among plots in the number of quadrats covered by each bromeliad species (Fig. 2). Plots I and II were covered by both bromeliad species, whereas plot III was covered only by A. distichantha (Fig. 2)

In January 1996, we recorded 127 seeds and 176 seedlings of $A$. praecox. Seed and seedling densities of $A$. praecox were not significantly different in quadrats with and

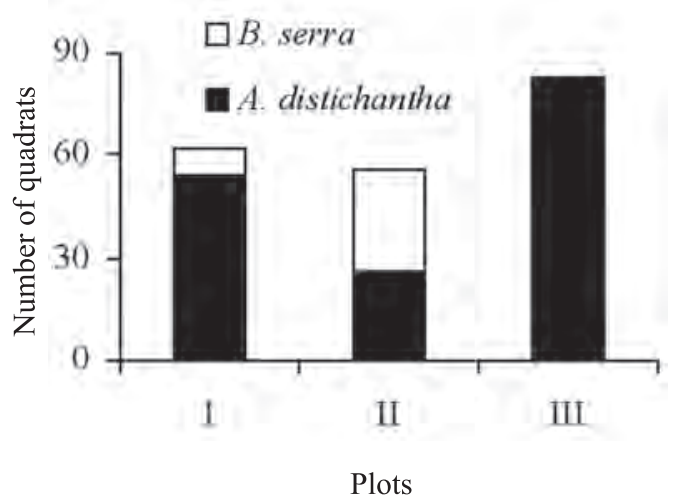

Fig. 2. Number of quadrats covered by bromeliads A. distichantha and B. serra in three plots (I, II, and III) of the 'quebrachal'. Each plot had a total of 150 quadrats of 100 $\mathrm{cm}^{2}$ each. $\mathrm{Y}$ axis number of quadrats, $\mathrm{X}$ axis plots.

without bromeliads (Wilcoxon, seeds $p>0.10$ and seedlings $p>0.20$; Fig. 3). Variability in seed and seedling density of $A$. praecox was higher within each plot than for the whole set of plots (Table 1).

Seed density was higher in quadrats covered by bromeliad leaves than inside bromeliad plants (Wilcoxon, $p<0.05$ ) (Fig. 4). In contrast, there was no significant difference in seedling density in quadrats beneath bromeliad leaves or covered by their bases (Wilcoxon, $p>0.10$ ), due to differences among plots (Fig. 4). In plots I and II, seedling density was higher beneath bromeliad leaves, whereas in plot III seedling density was higher in quadrats occupied by bromeliad bases (Fig. 4).

TABLE 1

Coefficients of variation (C.V.) for the number of quadrats with and without bromeliads, and for the density of seeds and seedlings of A. praecox in quadrats with and without bromeliads

\begin{tabular}{|c|c|c|c|c|c|c|c|c|}
\hline & \multirow[b]{3}{*}{$\mathrm{n}$} & \multirow[b]{3}{*}{ Unit } & \multicolumn{2}{|c|}{ Quadrats } & \multicolumn{2}{|c|}{ Seeds } & \multicolumn{2}{|c|}{ Seedlings } \\
\hline & & & \multicolumn{2}{|c|}{ Bromeliads } & \multicolumn{2}{|c|}{ Bromeliads } & \multicolumn{2}{|c|}{ Bromeliads } \\
\hline & & & With & Without & With & Without & With & Without \\
\hline Plot I & 3 & Transect & 41.15 & 28.99 & 34.32 & 49.67 & 52.18 & 28.55 \\
\hline Plot II & 3 & Transect & 69,09 & $4 \mathrm{I} .16$ & 155.27 & 12.38 & 71,69 & 52.03 \\
\hline Plot III & 3 & Transect & 1669 & 20.68 & 44,05 & 59.28 & 68.19 & 114.07 \\
\hline General & 3 & Plots & 21.16 & 17.08 & 26.62 & 12.64 & 19,44 & 66.69 \\
\hline
\end{tabular}

For each plot 3 transects were used, while at the broader scale (i.e. General) 3 plots were used. 

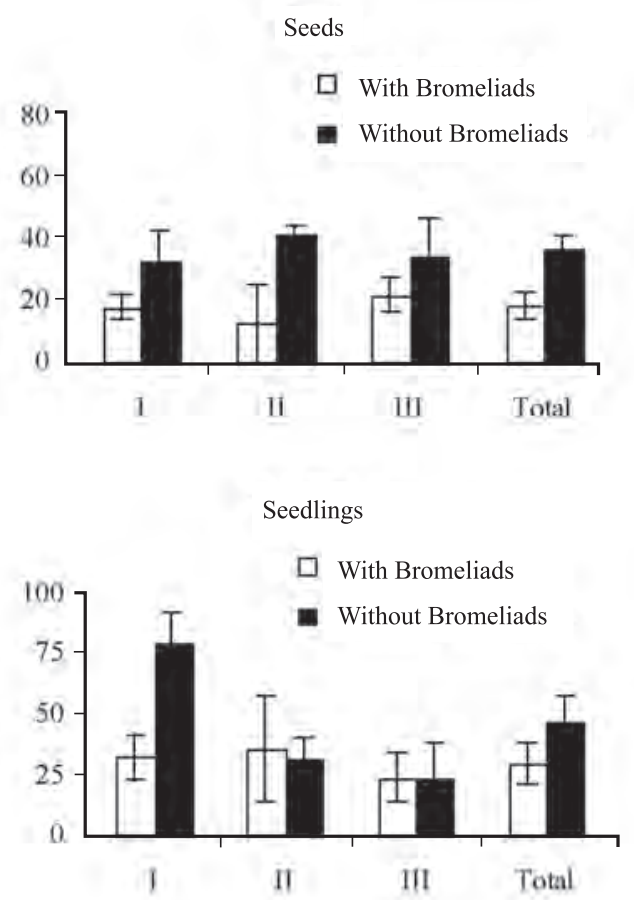

Fig. 3. Seed and seedling density (average \pm s.e.m.) of A. praecox in quadrats with and without bromeliads for each plot (I, II, or III) and for all of them together (Total). Y axis seedlings or seeds $/ \mathrm{m}^{2}, \mathrm{X}$ axis plots.

Seedling survival of A. praecox was much higher in plot $\mathrm{I}$ than in the others $\left(\chi^{2}{ }_{2 \text { g.l. }}=\right.$ 26.98; $p<0.001$; Fig. 5). Seedling survival seemed to be slightly higher in quadrats with bromeliads for all plots, but significant differences were observed only in plot $\mathrm{I}\left(\chi^{2}{ }_{1}\right.$ g.l. $=$ 3.92; $p=0.048$; Fig. 5). No seedling survived inside the bromeliad tanks.

\section{DISCUSSION}

Bromeliad colonies increase the heterogeneity of the forest floor by producing a subdivision of the understorey environment. About half of the forest floor was covered by bromeliads, and within this area it was further subdivided into subareas covered by their leaves or their bases. Similar or even higher cover of the understorey plants has been observed in other temperate and tropical forests
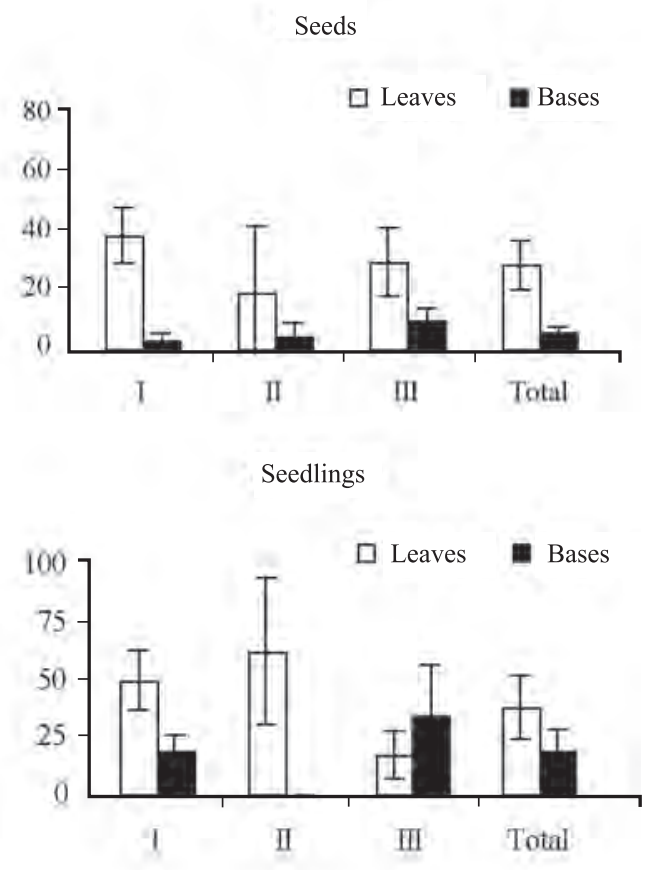

Fig. 4. Seed and seedling density (average \pm s.e.m.) of $A$. praecox at different locations in quadrats with bromeliads for each plot (I, II, or III) and for all of them together (Total). Y axis seedlings or seeds $/ \mathrm{m}^{2}, \mathrm{X}$ axis plots.

where woody species regeneration is affected by the understorey (Young 1991, George and Bazzaz 1999a, Marod et al. 1999, Tabarelli and Mantovani 2000).

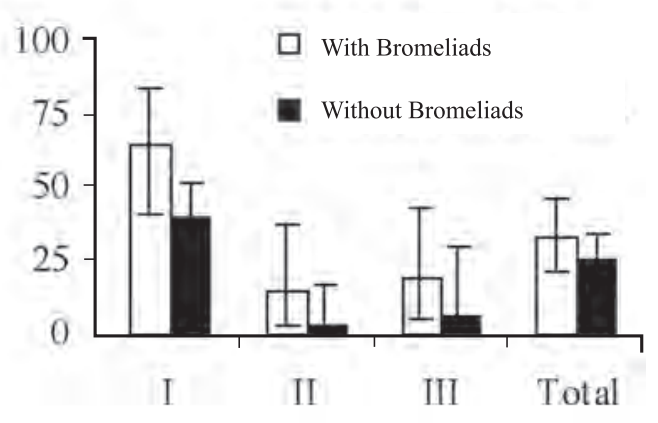

Fig. 5. Seedling survival of $A$. praecox in quadrats with and without bromeliads in 3 plots of the 'quebrachal' (I, II, and III) and for all plots together (Total). Y axis percentage of seedling survival, $\mathrm{X}$ axis plots. Vertical bars denote $95 \%$ confidence intervals based on binomial distribution. 
A higher heterogeneity allows a higher number of habitats to be colonized by woody seedlings (Sugita and Tani 2001). A. praecox seedlings were recorded in all habitats of these bromeliad colonies. This pattern may be the result of several factors acting on seed availability and germination. A high seed availability of A. praecox was expected due to the high density of its adult trees in the analyzed area (Lewis et al. 1997, Barberis et al. 1998, Barberis et al. 2002). Moreover, seed germination of this species occurs almost immediately when seeds are exposed to favorable conditions (C. Alzugaray, unpublished). However, it should be noted that even though seed availability and germination rate may be very high regardless of forest floor environment differences in seedling growth and survival in different microhabitats may later result in different seedling and sapling availability (Grubb 1977).

Seed density of A. praecox was similar in quadrats with and without bromeliads, but quadrats beneath bromeliad leaves had higher seed density than inside bromeliad tanks. In contrast, in a previous seed-rain study, convex sectors with bromeliads received more seeds than sectors without them (91 and 40 seeds $/ \mathrm{m}^{2} /$ year respectively) (Barberis 1998). Differences in seed rain among sectors were possibly related to adult distribution of A. praecox (Barberis et al. 1998, Barberis et al. 2002). In plots of the present study, we estimated about 67 seeds $/ \mathrm{m}^{2}$ of A. praecox (i.e. combined density of 39 seedlings $/ \mathrm{m}^{2}$ and 28 seeds $/ \mathrm{m}^{2}$ ). The actual seed density may have been underestimated because even though we recorded whether there were seeds inside bromeliad tanks, we did not open them in order to have a more accurate estimate.

In the present study, seedling density of A. praecox was similar in quadrats with and without bromeliads, and even in quadrats with bromeliads seedling density was similar inside bromeliad bases and beneath their leaves. This seedling density was much higher than the average of a 5-year study of the annual recruitment of woody species in convex sectors with bromeliads of the same stand of forest, where we observed an average density of 11 seedlings $/ 100 \mathrm{~m}^{2} /$ year of A. praecox (Barberis 1998). However, it should be noted that this previous demography study started in July, so that the period from germination to establishment, which is the most critical phase to disturbance and environmental effects for many plant populations (Harper 1977), was not included.

Seedling survival was similar in quadrats with and without bromeliads. A similar pattern was observed in the previous long-term demographic study (Barberis 1998). Seedling survival was much higher in quadrats beneath bromeliad leaves than inside bromeliad tanks, and although we recorded many seedlings germinated inside bromeliad tanks all of them died within six months, probably due to anoxia. This pattern contrasts with the regeneration of a dominant shrub (Erythroxylon ovalifolia Roxb.) in certain Brazilian restingas, where seedling survival not only was increased inside the tank of a terrestrial bromeliad (Neoregelia cruenta (Graham) L.B. Smith), but also seedling establishment only occurred inside this bromeliad (Fialho 1990).

Most seedlings of A. praecox were recruited on ground microsites between bromeliad plants or beneath their leaves, whereas recruitment on non-ground microsites (e.g. ant-nests, cattledung or fallen logs) was almost nil. This result based on data for one species (A. praecox) in just one area (Las Gamas) should be cautiously considered because preferences for seedling recruitment in certain microsites depends on the abundance of the dominant understorey plant, and the life history of the tree species considered (Taylor and Qin 1988,Takahashi 1997, Takahashi and Kohyama 1999, Sugita and Tani 2001). For example, in temperate forests of Japan, Abies mariesii Mast. showed a high preference for non-ground microsites (e.g. mounds or fallen logs) in stands where bamboo density was high, and low preference for these microsites in stands where bamboo density was low, whereas Tsuga diversifolia Mast. always showed preference for non-ground microsites (Sugita and Tani 2001). Similarly, in other forests of Japan, seedlings of Picea glehnii Mast. that established mainly in fallen logs dominate 
forests with Sasa Makino \& Shibata spp. (bamboo species) understorey, while seedlings of Abies sachalinensis Mast. occurs abundantly on the ground and therefore dominate forests without a Sasa spp. understorey (Takahashi 1997, Takahashi and Kohyama 1999). A similar pattern was suggested by Taylor and Qin (1988) who reported that the abundance of early successional Betula utilis D.Don increased in Chinese forests with dense bamboo cover because its seedlings regenerated on mounds and fallen logs, whereas the abundance of late successional Abies faxoniana Rehder \& Wilson decreased because its seedlings regenerated mainly on the ground. Differences in microhabitat preferences for seedling establishment between species, plus differences in density of the dominant understorey plant may facilitate species coexistence in forests (Takahashi and Kohyama 1999).

Summing up, the lack of differences of A. praecox regeneration among different microsites may be related to the low density of the bromeliads and/or to the natural history of the analyzed tree species. As we pointed out previously, these data based on just one species in one area should be cautiously considered. Thus, an experimental approach should be used to understand the mechanisms of seedling recruitment and survival in face of bromeliad colony presence.

\section{ACKNOWLEDGMENTS}

We greatly appreciate the logistic support given by Luis Schaumburg and Rodolfo Comuzzi from Las Gamas, Ministerio de Agricultura y Ganadería de Santa Fe. Nélida J. Carnevale, Susana R. Feldman and an unknown reviewer made useful comments that improved the manuscript. We acknowledge CONICET and Facultad de Ciencias Agrarias, Universidad Nacional de Rosario for financial support.

\section{RESUMEN}

En varios bosques tropicales y subtropicales, las plantas del sotobosque actúan como filtro ecológico que afecta diferencialmente la regeneración de las especies leñosas.
En los bosques de Schinopsis balansae (Anacardiaceae) del Chaco Oriental existen densas colonias de bromeliáceas terrestres que afectarían su regeneración al interceptar el agua de lluvia y los propágulos dentro de sus tanques. Estas bromeliáceas tienen distribución agrupada dejando espacios libres entre ellas. Describimos la heterogeneidad de tres colonias y analizamos como afectan la regeneración de Acacia praecox. En enero 1996, colocamos en cada colonia tres transectos con 150 parcelas de $100 \mathrm{~cm}^{2}$. En cada parcela registramos el tipo de cobertura (i.e. bromeliáceas, hierbas, hojarasca ó suelo desnudo) y la presencia de semillas o plántulas de A. praecox. En julio 1996, registramos la supervivencia de plántulas. Las colonias de bromiliáceas mostraron una alta heterogeneidad interna. Casi la mitad de las 450 parcelas estuvo cubierto por dos bromeliáceas terrestres. Aechmea distichantha se registró en $81 \%$ de las parcelas con bromeliáceas y Bromelia serra en las otras. Todas las parcelas estuvieron cubiertas por hojarasca. La mitad de ellas estuvieron cubiertas por hojas de bromeliáceas y el resto ocupado por sus bases. Donde no había bromeliáceas, el suelo estuvo cubierto por mantillo $(83 \%)$, herbáceas $(11 \%)$, u otros. En enero registramos 127 semillas y 176 plántulas de $A$. praecox. La densidad de ambas fue similar en parcelas con y sin bromeliáceas, pero su variabilidad fue mayor dentro de cada colonia que entre ellas. La densidad de semillas fue mayor debajo de las hojas de bromeliáceas que dentro de las plantas. La supervivencia de plántulas fue superior en parcela con bromeliáceas en sólo una de las tres colonias. Ninguna plántula sobrevivió dentro de las bromeliáceas. Aparentemente, las colonias de bromeliáceas no tienen efecto sobre la regeneración de A. praecox. Se presentan argumentos para explicar el patrón observado.

Palabras clave: bromelias, Chaco, heterogeneidad, regeneración, Schinopsis balansae, sotobosque.

\section{REFERENCES}

Abe, M., H. Miguchi \& T. Nakashizuka 2001. An interactive effect of simultaneous death of dwarf bamboo, canopy gap, and predatory rodents on beech regeneration. Oecologia 127: 281-286.

Barberis, I.M. 1998. Distribución y regeneración de especies leñosas en relación con la heterogeneidad ambiental en un bosque de Schinopsis balansae del sur del Chaco oriental. M. Sc. Thesis, Universidad de Buenos Aires, Argentina. 128 p.

Barberis, I.M., E.F. Pire \& J.P. Lewis. 1998. Spatial heterogeneity and woody species distribution in a Schinopsis balansae (Anacardiaceae) forest of the Southern Chaco, Argentina. Rev. Biol. Trop. 46: 515-524.

Barberis, I.M., W.B. Batista, E.F. Pire, J.P. Lewis \& R.J.C. León. 2002. Spatial distribution of woody populations 
in relation to local environmental heterogeneity in a humid-subtropical-Chaco forest, Argentina. J. Veg. Sci. 13: 607-614.

Beatty, S.W. \& E.L. Stone. 1986. The variety of soil microsites created by treefalls. Can. J. For. Res. 16: 539-548.

Bitlloch, E. \& H.A. Sormani. 1997. Los enclaves forestales de la región chaqueño-misionera. Ciencia Hoy 7: 41-52.

Bordón, A. 1978. Las bromeliáceas terrestres. Report INTA Presidencia Roque Saenz Peña, Argentina.

Brokaw, N.V.L. 1983. Groundlayer dominance and apparent inhibition of tree regeneration by Aechmea magdalenae (Bromeliaceae) in a tropical forest. Trop. Ecol. 24: 194-200.

Denslow, J.S., E. Newell \& A.M. Ellison. 1991. The effect of understory palms and cyclanths on the growth and survival of Inga species. Biotropica 23: 225-234.

Espino, L.M., M.A. Seveso \& M.A. Sabatier. 1983. Mapa de suelos de provincia de Santa Fe. Tomo II. MAGSF and INTA EERA, Rafaela, Argentina. 220 p.

Fialho, R.F. 1990. Seed dispersal by a lizard and a tree frog - effect of dispersal site on seed survivorship. Biotropica 22: 423-424.

George, L.O. \& F.A. Bazzaz. 1999a. The fern understory as an ecological filter: emergence and establishment of canopy-tree seedlings. Ecology 80: 833-845.

George, L.O. \& F.A. Bazzaz. 1999b. The fern understory as an ecological filter: growth and survival of canopytree seedlings. Ecology 80: 846-856.

Grubb, P.J. 1977. The maintenance of the species-richness in plant communities: the importance of the regeneration niche. Biol. Rev. 52: 107-145.

Hansell, M.H. 1993. The ecological impact of animal nests and burrows. Funct. Ecol. 7: 5-12.

Harper, J.L. 1977. Population biology of plants. Academic, London. 892 p.

Itoh, A. 1995. Effects of forest floor environment on germination and seedling establishment of two Bornean rainforest emergent species. J. Trop. Ecol. 11: 517-527.

Kolasa, J. \& S.T.A. Pickett. 1991. Ecological heterogeneity. Springer, New York. 332p.

Lewis, J.P. \& E.F. Pire. 1981. Reseña sobre la vegetación del Chaco santafesino. I.N.T.A., Serie Fitogeográfica 18. Buenos Aires, Argentina. 42 p.
Lewis, J.P. 1991. Three levels of floristical variation in the forests of Chaco, Argentina. J. Veg. Sci. 2: 125-130.

Lewis, J.P., E.F. Pire \& I.M. Barberis. 1997. Structure, physiognomy and species composition of a Schinopsis balansae (Anacardiaceae) forest in the Southern Chaco, Argentina. Rev. Biol. Trop. 45: 1013-1020c.

Lewis, J.P., E.F. Pire \& J.L. Vesprini. 1994. The mixed dense forest of the Southern Chaco. Contribution to the study of flora and vegetation of the Chaco VIII. Candollea 49: 159-168.

Marod, D., U. Kutintara, C. Yarwudhi, H. Tanaka \& T. Nakashisuka. 1999. Structural dynamics of natural mixed deciduous forest in western Thailand. J. Veg. Sci. 10: 777-786.

Martínez Crovetto, R. 1980. Estudios fitosociológicos en el sotobosque de los quebrachales del noroeste de Corrientes (República Argentina). Bol. Soc. Arg. Bot. 19: 315-329.

Morello, J. \& J. Adámoli. 1974. Las grandes unidades de vegetación y ambiente del Chaco argentino. Segunda parte: Vegetación y ambiente de la provincia del Chaco. I.N.T.A., Serie fitogeográfica 13. Buenos Aires, Argentina. $130 \mathrm{p}$.

Nakashizuka, T. 1989. Role of uprooting in composition and dynamics of an old-growth forest in Japan. Ecology 70: 1273-1278.

Orians, G.H. 1982. The influence of tree-falls in tropical forests in tree species richness. Trop. Ecol. 23: 255-279.

Pire, E.F. \& D.E. Prado. 2001. Pautas empíricas para un manejo sustentable de los bosques de la cuña boscosa santafesina, p. 257-260. In C. Bertonatti \& J. Corcuera, J. (eds.). Situación ambiental argentina 2000. Fundación Vida Silvestre Argentina, Buenos Aires.

Pire, E.F., P.S. Torres, O.D. Romagnoli \& J.P. Lewis. 1991. The significance of ant-hills in depressed areas of the Great Chaco. Rev. Biol. Trop. 39: 71-76.

Prado, D.E. 1993. What is the Gran Chaco vegetation in South America? I. A review. Contribution to the study of flora and vegetation of the Chaco V. Candollea 48: 145-172.

Schupp, E.W. 1995. Seed-seedling conflicts, habitat choice, and patterns of plant recruitment. Am. J. Bot. 82: 399409.

Streng, D.R., J.S. Glitzenstein \& P.A. Harcombe. 1989. Woody seedling dynamics in an east Texas floodplain forest. Ecol. Monogr. 59: 177-204. 
Sugita, H. \& M. Tani. 2001. Difference in microhabitatrelated regeneration patterns between two subalpine conifers, Tsuga diversifolia and Abies mariesii, on Mount Hayachine, northern Honshu, Japan. Ecol. Res. 16: 423-433.

Svenning, J.C. 1999. Microhabitat specialization in a species-rich palm community in Amazonian Ecuador. J. Ecol. 87: 55-65.

Svenning, J.C. 2001. On the role of microenvironmental heterogeneity in the ecology and diversification of Neotropical rain-forest palms (Arecaceae). Bot. Rev. 67: 1-53.

Tabarelli, M. \& W. Mantovani. 2000. Gap-phase regeneration in a tropical montane forest: the effects of gap structure and bamboo species. Plant Ecol. 148: 149-155.

Takahashi, K. \& T. Kohyama. 1999. Size-structure dynamics of two conifers in relation to understorey dwarf bamboo: a simulation study. J. Veg. Sci. 10: 833-842.

Takahashi, K. 1997. Regeneration and coexistence of two subalpine conifer species in relation to dwarf bamboo in the understorey. J. Veg. Sci. 8: 529-536.

Taylor, A.H. \& Z. Qin. 1988. Regeneration patterns in oldgrowth Abies-Betula forests in the Wolong Natural Reserve, Sichuan, China. J. Ecol. 76: 1204-1218.

Wada, N. 1993. Dwarf bamboos affect the regeneration of zoochorous trees by providing habitats to acorn-feeding rodents. Oecologia 94: 403-407.

Young, K.R. 1991. Natural history of an understory bamboo (Chusquea sp.) in a tropical timberline forest. Biotropica 23: 542-554.

Zar, J.H. 1999. Biostatistical analysis. Prentice Hall, Upper Saddle River, U.S.A. 663 p. 
